МАШИН03НАВСТВО

UDC 621.865.8(031)

DOI https://doi.org/10.32838/2663-5941/2020.1-2/01

Polishchuk M.M.

National Technical University of Ukraine "Igor Sikorsky Kyiv Polytechnic Institute"

\title{
OPTIMIZATION OF MOBILE ROBOT PARAMETERS FOR SURFACES OF ARBITRARY ORIENTATION
}

Mobile robots of arbitrary orientation in the technological space are a new modification of mobile robots, known as robots of vertical movement or, in foreign publications, under the name Climber Robot. The difference between these robots is to equip them with devices to overcome the gravitational load while moving on surfaces of arbitrary orientation. Of particular relevance is the problem of creating robots of this type, if necessary, for the maintenance of high-altitude objects, such as skyscrapers, high-voltage power lines, bridges, viaducts, woodlands, etc. Of significant interest is the use of such robots in conditions of technological disasters.

The article describes a modified method for optimizing the design and technological parameters of a mobile robot, which is presented in the form of a multi-level technical system. The difference between the optimization methodologies is that the optimality criteria of each previous level are included in the objective function of each higher level of the technical system as variable factors. The article presents a fundamentally new design of the robot with storage of potential energy and its conversion into kinetic energy of movement of the robot. The results of modelling the process of movement of the robot on a vertical surface are also presented.

The presence of elastic energy accumulators can significantly increase the energy efficiency of mobile robots, since autonomous power sources with a limited energy resource are used in such robots. The proposed model for optimizing the parameters of the robot allows us to calculate the quasi-optimal values of the design and technological parameters of the robot, which is sufficient to ensure the efficient operation of mobile robots in various fields of industry and utilities.

Key words: mobile robot, stepping mechanism, climber robot, vertical movement robot.

Formulation of the problem. The creation of mobile robots of arbitrary orientation in the technological space is not limited only to the improvement of their retention systems on the movement surface. This type of robots, like any technical system, is a multi-level hierarchical system, which includes subsystems of gripping devices, motion drives and transmission. Therefore, the solution of the optimization problem of these subsystems requires the construction of a parametric model, in which relationships of optimization criteria at various levels of the hierarchical system should be shown.

Analysis of recent research and publications. The fundamentals of climbing robots modelling are rather widely described in works $[1$, p. $260 ; 2$, p. 35-36], though without solving the problem of reusing energy of motion. Modelling of vertical moving robots is devoted in work [3, p. 28], however without solving the problem of energy consumption of motion. Studies $[4$, p. $6 ; 5$, p. $2-4]$ contain descriptions of various models of robots. But in these works there are no designs for the recuperation of energy of motion. Known technical solutions $[6$, p. 8$]$ promote partial energy saving, for example, by using pulsed lifting mechanism. However, described system increases weight of robot, so it leads to increasing energy consumption. Therefore, the task of reducing energy consumption of the mobile robot movement is still relevant.

Setting objectives. To build a parametric model of a mobile robot, it is necessary to formulate and write down target functions for optimizing the design and technological parameters of each of its subsystems. Then establish the connection of optimization criteria at various levels of the hierarchical system and ultimately calculate the quasi-optimal values of the robot parameters that can ensure its effective operation.

Statement of the main material. In Fig. 1 shows a mobile robot $[7$, p. 4-6] realizing having the ability to accumulate potential energy at each previous step and converting it into kinetic energy of motion at each subsequent step of displacement. On the robot body 1 are mounted rotary pneumatic actuators 2 connected through a gear train 10 with running mechanisms 3 . When the elastic members 4 are 
compressed due to the rotation of the legs of the robot, the potential energy is accumulated during the first half of the step, and in the second half of the step, these elements convert the potential compression energy in the kinetic energy of the robot's motion. The kinematics and dynamics of such a robot are considered in more detail in the works [8, p. 117; 9].

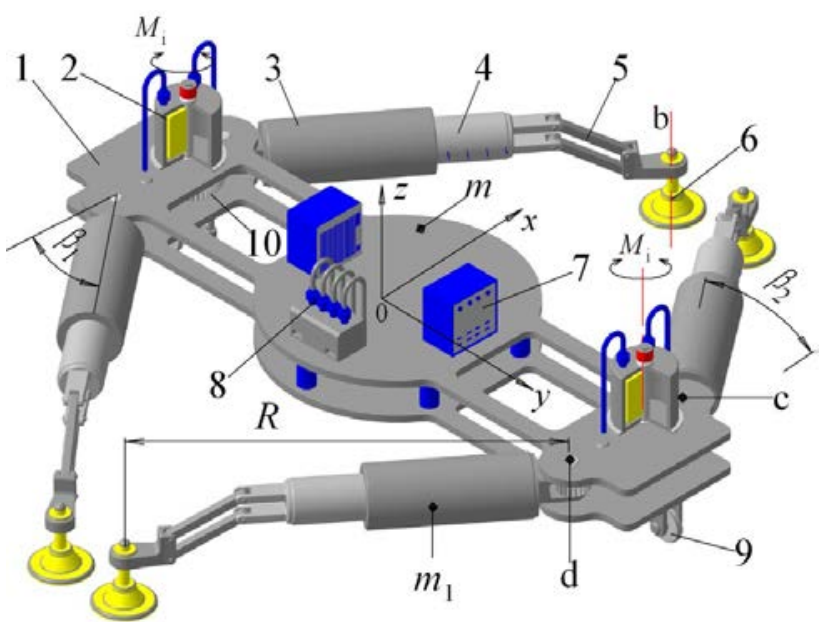

Fig. 1. The robot model of arbitrary orientation with the accumulation and transformation of energy

To implement a plane-parallel motion along the vertical, the robot is equipped with parallelograms 5 . The latter connect pedipulators with vacuum grippers 6 that hold the robot on a surface of arbitrary orientation. Also, the robot is equipped with a control unit 7 and a power supply module 8 . To overcome obstacles on the moving surface, the robot is additionally equipped with rolling bearings $9[10, p .14]$.

For designing walking mechanisms - pedipulators, it is necessary to synthesize analytical dependences for dynamic loads. According to the scheme on Fig. 2 pedipulators propulsive force is:

$$
F=F_{1}+F_{2},
$$

where: $F_{1}$ and $F_{2}$ - variable propulsive forces of the servos respectively on the first half-cycle of movement - at the stage $X_{1}$ and on the second half-cycle of movement - at stage $X_{2}$. At the stage of energy accumulation $X_{l}$ propulsive force of two pedipulators equals:

$$
F=\frac{2 M_{1} i}{n z}-2 f,
$$

where: $M$ - torque of the servomotor, Nm; $i$ - transmission ratio of pedipulator servomotor; - the angle of pedipulator axis rotation, degrees, $0 \leq \beta_{1} \leq \beta^{\max }$ (here the values $\beta_{1}=0$ and $\beta_{1}=\beta^{\max }$ correspond to the beginning and end of the pedipulator axis rotation); $n$-module and $z$-number of $\operatorname{cogs}$ of the wheel (gear); $f$ - resistance force $(N): f=J \sin \beta_{1}$ where: $J$ - variable force of the elastic element, N:

$$
J=P_{\min }+j x=P_{\min }+j\left(R_{1}-R_{1} \cos \beta_{1}\right)=P_{\min }+j R_{1}\left(1-\cos \beta_{1}\right)
$$

where: $P_{\min }-$ preload clamping force $(\mathrm{N})$, $j$ - stiffness $(\mathrm{N} / \mathrm{m})$ and $x$ - the value of deformation of the elastic element (potential energy storage), $m$.

At the stage of accumulated energy usage $X_{2}$ when the servomotor is switched off (that is, when $\beta_{1} \geq \beta_{2} \leq \beta_{2}{ }^{\max }$ and the beginning and the end of the axis rotation corresponds to the values $\beta_{2}=\beta_{1}$ and $\beta_{2}=\beta_{2}^{\max }$ ) propulsive force is equal to:

$$
\begin{aligned}
& F_{2}=-J \sin \beta_{2}+P_{\min }=j x \sin \beta_{2}+P_{\min }= \\
& =-\left[j R_{1}\left(1-\cos \beta_{2}\right)\right] \sin \beta_{2}+P_{\min }
\end{aligned},
$$

where $\beta_{2}$ - the angle of the pedipulator axis rotation on the stage of energy recycling.

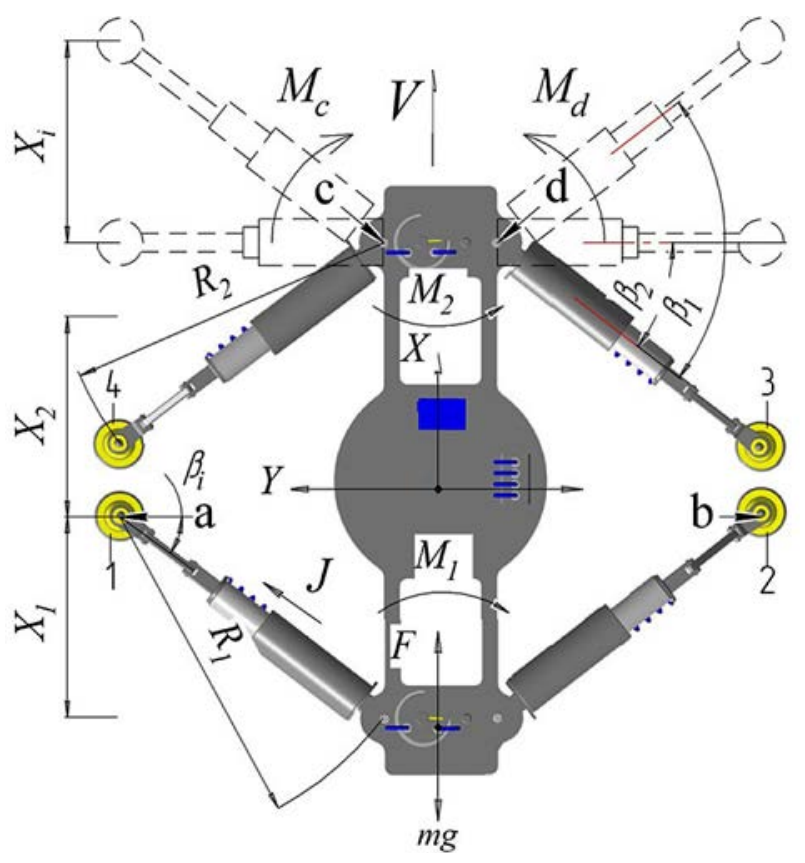

Fig. 2. Loading diagram of pedipulator (plan view): grippers 1,2-attached to the surface and 3,4-free from engagement with the surface, respectively

From (4) it is obvious that during the rotation of pedipulators deformation value of elastic elements $x$ decreases from value $x=R_{1}\left(1-\cos \beta_{2}\right)$ to value $x=0$, which means the end of motion using previously accumulated energy above other pair of pedipulators 3 and 4 (see. Fig. 2) which are disengaged from the surface of movement perform free movement. As noted above, the robot body during the full cycle travels distance equal to $X_{1}+X_{2}$. At the same time disabled (free from engagement with the movement surface) grippers 3 and 4 covers double distance: $2\left(X_{1}+X_{2}\right)$, due to the simultaneous movement of robot's body and grippers themselves. During this free movement of pedipulators 3 and 4 their elastic elements are not deformed, and therefore disconnected from the sur- 
face grippers move along the arc with centers in corresponding points "c" and " $d$ " and radius $R_{2} \geq R_{1} \cos \beta_{1}$ under the influence of the torques:

$$
M_{c}=M_{d}=M_{1} i
$$

and with linear speed:

$$
V_{i}=V+\omega R_{2}=V+\omega_{1} i R_{2}
$$

where: $V$ - linear speed of the robot, $\mathrm{m} / \mathrm{s}$; $V=\omega_{1} i R_{1} \cos \beta_{1} ; \omega$ and $\omega_{1}-$ respectively, the angular speed of disconnected pedipulators and the main servomotor of the robot, $\mathrm{rad} / \mathrm{s} ; i$ - transmission ratio of pedipulator servomotor.

Clearly, unlike constant speed of free actuators $\omega R_{2}=$ Const , relative speed of the robot's body and enabled actuators is variable and depends on the rotation angle $\cos \beta_{1}$ of the working actuators.

Solving the optimization problem. Let's consider stepping robot for vertical movement as a hierarchical multi-level system. Its scheme is shown above in Fig. 2. The robot contains subsystem for retaining on the surface of movement represented by vacuum grippers (see position 6 in Fig. 1), transmission with potential energy accumulators capable to transform this energy into kinetic energy of motion and servomotors to drive pedipulators (stepping mechanisms).

The formula of vacuum grip force $Q$, that holds the robot on the surface of movement, can be used as objective function of the 1 st level:

$$
Q=\frac{\pi d^{2}}{4} K_{S}\left(p_{a} K_{a}-p_{v}\right) K \rightarrow \max
$$

under the constraints:

$$
\begin{aligned}
& (25 \leq d \leq 100) 10^{-3} ; 0,9 \leq K_{S} \leq 1 ;\left(50 \leq p_{\nu} \leq 80\right) \times 10^{3} ; \\
& 0,65 \leq K \leq 0,85
\end{aligned}
$$

where: $d$-diameter of the vacuum zone under the suction cup, $(\mathrm{m}) ; \neq d^{2} / 4$ - area that is bounded by suction cup inner contour $\left(\mathrm{m}^{2}\right) ; K_{s}$ - suction area reduction coefficient due to the seal deformation; $p_{a}=101 \times 10^{3}(\mathrm{~Pa})$ - atmosphere pressure; $p_{v}(\mathrm{~Pa})-$ pressure inside the suction chamber; $K_{a}$ - coefficient to take into account changes in atmospheric pressure $\left(K_{a}=0,9\right) ; K$ - coefficient to consider air influx in the chamber seal of suction cup in place of its contact with the surface of movement.

Maximum and minimum values of the objective function are:

$$
\begin{aligned}
& Q_{\max }=\frac{\pi d_{\max }^{2}}{4} K_{s}^{\max }\left(p_{a} K_{a}^{\max }-p_{v}^{\min }\right) K_{\max } ; Q_{\min } \\
& =\frac{\pi d_{\min }^{2}}{4} K_{s}^{\min }\left(p_{a} K_{a}^{\min }-p_{v}^{\max }\right) K_{\min }
\end{aligned}
$$

The grip force also affects the permissible stiffness value $\boldsymbol{j}$ of elastic element, that accumulates potential energy and converts it into kinetic energy of motion, because the inequality should be true:

$$
F_{T}>J_{\text {max }} \Rightarrow \mu Q_{\max }>P_{\min }+j R_{2}\left(1-\cos \left(45^{\circ}\right)\right),
$$

where: $P_{\min }-$ minimum value of preliminary compression of the elastic element, $N$;

$R_{2}$ - length of the robot leg in a free state (for our solution $R_{2}=0,2 \mathrm{~m}$ ); $\beta=45^{\circ}$ - robot leg rotation angle.

We find the elastic element stiffness value from the expression (9)

$$
j<\frac{\mu Q_{\max }-P_{\min }}{R_{2}\left(1-\cos \left(45^{\circ}\right)\right)},
$$

As it is stated above, the difference of the proposed method is in a mutual relationship between the criteria and parameters that characterize each next level of the system. Therefore, we take force $f$ of resistance to the movement coming from elastic element decompression as one of the objective functions on the second level of hierarchy for our technical system. When the robot leg rotates in the range $0 \leq \beta_{1} \leq 45^{\circ}$ :

$$
\begin{aligned}
& f=J \sin \left(45^{\circ}-\beta_{1}\right)=P_{\min } \sin \left(45^{\circ}-\beta_{1}\right)+ \\
& +j R_{2}\left(1-\frac{\cos 45^{\circ}}{\cos \left(45^{\circ}-\beta_{1}\right)}\right) \sin \left(45^{\circ}-\beta_{1}\right) \rightarrow \min ,
\end{aligned}
$$

where $j$ - elastic element(spring) stiffness (see Fig. 1, item 4): $1000 " j^{\prime \prime} 4000\left(\frac{N}{m}\right)$.

Obviously, increase of the elastic element will lead to the objective function growth. In order to evaluate the objective function behaviour with angle $\beta_{l}$ (turn of the the robot leg) change, we find the derivative:

$$
\frac{d f}{d \beta_{1}}=-\left(P_{\min }+j R_{2}\right) \cos \left(45^{\circ}-\beta_{1}\right)+j R_{2}\left(\frac{\cos 45^{\circ}}{\cos ^{2}\left(45^{\circ}-\beta_{1}\right)}\right) .
$$

It is easy to estimate that the derivative is negative for $\beta_{1}=45^{\circ}$ and positive for $\beta_{1}=0$. This means that the objective function reaches maximum within the $\beta_{1}$ range and minimum value $f=0$ at the angle $\beta_{I}=45^{\circ}$. The stiffness of the elastic element equal to

$$
j<\frac{\left(m+2 m_{1}\right) g L-2 P_{\min } x_{\max }}{2 x_{\max }^{2}},
$$

After substituting $Q=Q_{\max }$ and $W=0$, we get a formula to find the maximum value of robot movement force depending on the stiffness $j$ and the angle $\beta_{o}$ :

$$
\begin{aligned}
& F_{1}^{\max }=2 \sqrt{\left(\mu Q_{\max }\right)^{2}-\left(J_{o} \cos \left(45^{o}-\beta_{o}\right)\right)^{2}}+ \\
& +\left(m+4 m_{1}\right) g+2 J_{o} \sin \left(45^{o}-\beta_{o}\right)
\end{aligned},
$$

where the elastic element force is equal to

$$
J_{o}=P_{\min }+j R_{2}\left(1-\frac{\cos 45^{\circ}}{\cos \left(45^{\circ}-\beta_{\circ}\right)}\right) .
$$


For practical application formula (14) may be expressed in terms of dimensionless quantities:

$$
y=2 \sqrt{\left(q_{o}\right)^{2}-\left(J_{1} \cos \left(45^{o}-\beta_{o}\right)\right)^{2}}+1+2 J_{1} \sin \left(45^{o}-\beta_{o}\right),
$$

$$
\begin{gathered}
\text { where: } y=\frac{F_{1}^{\max }}{G_{2}} ; q_{o}=\frac{\mu Q_{\max }}{G_{2}} ; P_{o}=\frac{P_{\min }}{G_{2}} ; j=k j_{o} ; \\
h_{o}=\frac{j_{0} R_{2}}{G_{2}} ; J_{1}=P_{o}+k h_{o}\left(1-\frac{\cos 45^{\circ}}{\cos \left(45^{\circ}-\beta_{o}\right)}\right) ;
\end{gathered}
$$

$j_{o}=100(\mathrm{~N} / \mathrm{m}) ; k-$ proportionality coefficient; $G_{2}=m_{2} g-$ weight of the robot.

Fig. 3 shows how the values of the parameter $y$ (curved lines) vary depending on the elastic element stiffness $j=k j_{o}$ and $y_{l}$ (straight lines) for different values of angle $\beta_{o}$ - the extreme value of angle $\beta_{l}$, when the drive force $F_{l}$ still has effect. The permissible force values $F_{1}=y G_{2}$ and stiffness $j=k j_{o}$ are in the region located between the straight line and the corresponding curve.

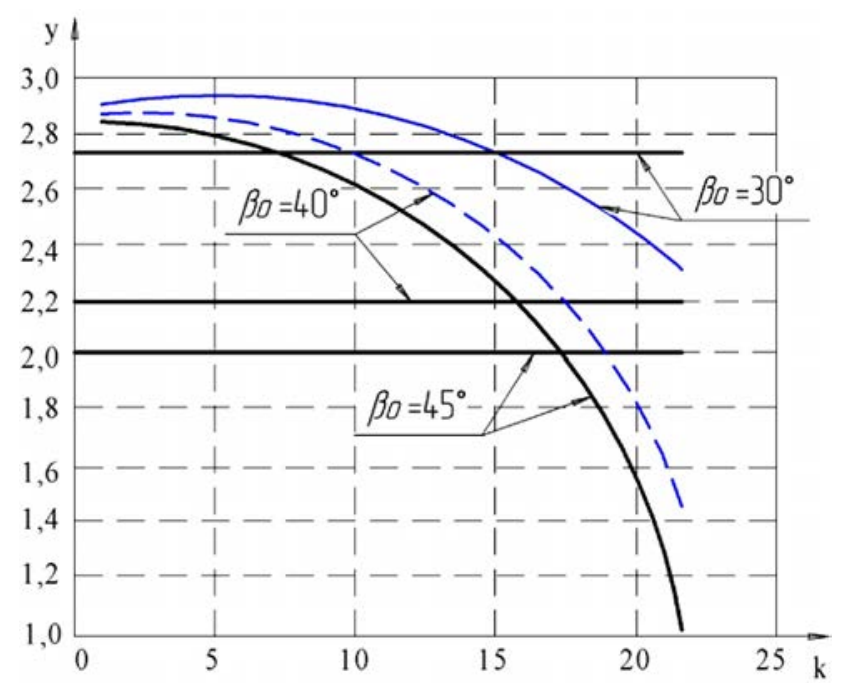

Fig. 3. Areas of permissible values of robot drive force $F_{1}$ and stiffness $\boldsymbol{j}$ - between the straight line and corresponding curve

Now let's choose objective function for the second stage of robot movement. $F_{2}$, is a force of elastic element decompression applied to the robot with disabled drives:

$$
\begin{gathered}
F_{2}=-\left(P_{\min }+j R_{2}\left(1-\frac{\cos 45^{\circ}}{\cos \left(45^{\circ}-\beta_{1}\right)}\right)\right) \sin \left(45^{\circ}-\beta_{1}\right) \rightarrow \max ; \\
45^{\circ} \leq \beta_{1} \leq 90^{\circ}
\end{gathered}
$$

In order to find extremal points of $F_{2}$ we calculate the derivative and equate it to zero:

$$
\frac{\partial F_{2}}{\partial \beta_{1}}=\left(P_{\min } \cos \left(45^{\circ}-\beta_{1}\right)+j R_{2}\left(\cos \left(45^{\circ}-\beta_{1}\right)-\frac{\cos 45^{\circ}}{\cos ^{2}\left(45^{\circ}-\beta_{1}\right)}\right)\right)=0
$$

From this equation we find:

$$
\cos \left(45^{\circ}-\beta_{1}\right)=\sqrt[3]{\frac{j R_{2} \cos 45^{\circ}}{P_{\min }+j R_{2}}} \Rightarrow \beta_{1}=45^{\circ}+\arccos \left(\sqrt[3]{\frac{j R_{2} \cos 45^{\circ}}{P_{\min }+j R_{2}}}\right)
$$

Since the derivative changes its sign from plus to minus when passing through the critical point, the function reaches a maximum at this point:

$$
F_{2}^{\max }=\left(P_{\min }+j R_{2}\left(1-\frac{\cos 45^{\circ} \sqrt[3]{P_{\min }+j R_{2}}}{\sqrt[3]{j R_{2} \cos 45^{\circ}}}\right)\right)\left(\sqrt{1-\sqrt[3]{\frac{\left(j R_{2} \cos 45^{\circ}\right)^{2}}{\left(P_{\min }+j R_{2}\right)^{2}}}}\right)
$$

Dependency between maximum value of drive force $F_{2}^{\max }$ and the stiffness of potential energy accumulator (elastic elements) $j$ is shown in Fig. 4. It is obvious that an increase of elastic element stiffness leads to the corresponding increase of the driving force $F_{2}$ in the second stage of robot movement.

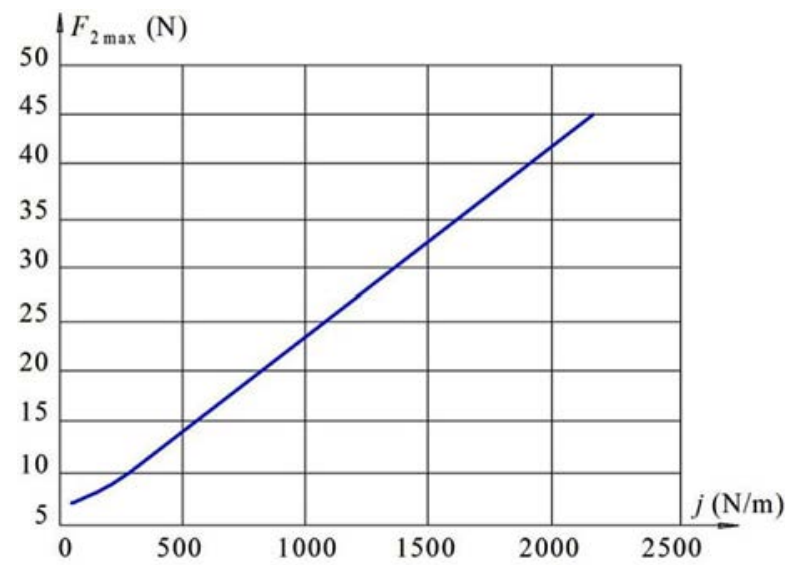

Fig. 4. Dependency between maximum values of driving force $F_{2}^{\max }$ and stiffness of elastic elements $\boldsymbol{j}(\mathrm{N} / \mathrm{m})$

However, it should be taken into account that increasing stiffness of elastic element counteracts robot movement force $F_{1}$ in the first stage of the movement and therefore there are some limitations (10). In the second stage of the movement $\left(45^{\circ} \leq \beta \leq 90^{\circ}\right)$ pedipulator drive is disabled in order to save energy so the robot moves only using accumulated energy. Therefore, stiffness values of elastic elements have dominant influence on the movement dynamics.

Conclusions. A mobile robot of arbitrary orientation with motion energy recovery modules allows increasing its energy efficiency due to the accumulation of potential energy at each previous step of movement and the conversion of this energy into kinetic energy of movement at each next step of movement.

The proposed model of parametric optimization of a walking mobile robot allows us to calculate the quasi-optimal values of its design parameters. These values are sufficient for the effective operation of a mobile robot of the specified type in various industries. 


\section{References:}

1. Apostolescu T., Udrea C., Duminica D., Ionascu G., Bogatu L., Laurenţiu A. and Maiorescu T. (2011), Development of a Climbing Robot with Vacuum Attachment Cups. Proceedings of International Conference On Innovations, Recent Trends And Challenges In Mechatronics, Mechanical Engineering And New High-Tech Products Development, MECAHITECH'11, vol. 3, 2011, p: 258-267.

2. Raju D., Jaju S. (2014), Developments in Wall Climbing Robots: A Review International Journal of Engineering Research and General Science, vol 2(3), p. 33-42.

3. Lam T.L., Yangsheng X. (2012). Tree Climbing Robot: Design, Kinematics and Motion Planning. Springer Heidelberg New-York , p. 28-29.

4. Yehya M., Hussain S., Wasim A., Jahanzaib M., Abdalla H. (2014). A Cost Effective and Light Weight Unipolar Electroadhesion Pad Technology for Adhesion Mechanism of Wall Climbing Robot. International Journal of Robotics and Mechatronics, vol. 2, № 1, 2014, p. 1-10.

5. Silva M., Tenreiro Machado J. (2012). A Survey of Technologies and Applications for Climbing Robots Locomotion and Adhesion. ISEP - Instituto Superior de Engenharia do Porto Portugal. Available at: http://cdn. intechweb.org/pdfs/10079.pdf.

6. Zheleznjak V.L., Zheleznjak I.F., Zheleznjak F.A. and Matveenko L.S. Vehicle. RU, Pat. 2068362. 27.10.1996.

7. Yampolskiy L.S., Polishchuk M.N., Persikov V.K. Method and device for movement of pedipulators of walking robot. UA, Pat. 111021. 10.03.2016.

8. Polishchuk M., Oliinyk V. (2018). Mobile climbing robot with elastic energy accumulators. Mechanics and Advanced Technologies, vol. 1(82), p. 116-122.

9. Polishchuk M.N., Oliinyk V.V. (2020). Dynamic Model of a Stepping Robot for Arbitrarily Oriented Surfaces. In: Hu Z., Petoukhov S., Dychka I., He M. (eds). Advances in Computer Science for Engineering and Education II. ICCSEEA 2019. Advances in Intelligent Systems and Computing, vol. 938. Springer, Cham.

10. M. Polishchuk, M. Tkach (2020). Mobile Robot with an Anthropomorphic Walking Device: Design and Simulation. FME Transactions. Volume 48, № 1, 2020. p. 13-20.

\section{ПоЛіщуК М.М. ОПТИМІЗАЦІЯ ПАРАМЕТРІВ МОБІЛЬНОГО РОБОТА ДЛЯ ПОВЕРХОНЬ ДОВІЛЬНОЇ ОРІЕНТАЦІї}

Мобільні роботи довільної орієнтації у технологічному просторі є новою модифікацією мобільних роботів, відомих як роботи вертикального переміщення, а в закордонних публікаціях - під терміном Climber Robot (робот-альпініст). Відмінність таких роботів полягає в оснащенні їх пристроями подолання гравітачійного навантаження під час руху на поверхнях довільної орієнтації. Особливу актуальність проблема створення роботів означеного типу набуває за необхідності технологічного обслуговування висотних об'єктів: хмарочоси, лінії високовольтних електропередач, мостів, віадуків, деревних масивів тощо. Неабиякий інтерес викликає застосування таких роботів в умовах техногенних катастроф.

У статті описаний модифікований метод оптимізачї конструктивних і технологічних параметрів мобільного робота, який представлений у вигляді багаторівневої технічної системи. Різниия між методологіями оптимізації полягає в тому, що критерії оптимальності кожного попереднього рівня включаються в цільову функиію кожного вищого рівня технічної системи як змінні фактори.

У статті представлено принципово нову конструкиію робота зі зберіганням потенційної енергії та перетворенням ї̈ в кінетичну енергію руху робота. Представлені також результати моделювання руху робота по вертикальній поверхні.

Наявність пружних акумуляторів енергї дозволяє суттєво підвищити енергетичну ефективність мобільних роботів, оскільки в подібних роботах використовуються автономні джерела живлення 3 обмеженим енергетичним ресурсом. Запропонована модель оптимізаиії параметрів робота дозволяє обчислювати квазіоптимальні значення його конструктивних і технологічних параметрів, щзо достатньо для забезпечення ефективної експлуатаціїмобільних роботів у різнихгалузях промисловості та комунального господарства.

Ключові слова: мобільний робот, крокові механізми, робот-альпініст, робот вертикального переміщення. 